DOI https://doi.org/10.36059/978-966-397-158-2/1-20

\title{
SECURITY AS A DETERMINANT OF DEMOCRATIC TRANSFORMATION: THREAT PARAMETERS AND EVALUATION CRITERIA
}

\section{Kormych L. I.}

\section{INTRODUCTION}

Understanding security as a state of protection for the vital interests of the individual, society, state and world community determines its special role in the process of democratic transformation. This, in turn, necessitates the analysis of security threats, specifying each actor and object, as well as evaluating the effectiveness of models and mechanisms for preventing or overcoming threats. The perspective modeling of security processes and the prediction of possible security threats in an era of global change should be multidimensional. In fact, the degree of effectiveness of such models and the effectiveness of the mechanisms of their implementation determines both the possibility and the time frames of creating a secure environment for successful implementation of democratic reforms. This process, with certain limits due to national peculiarities, is based on the laws that determine the phenomenon of globalization. Priority is given to the category of security threats in the analysis of security status and the creation of normal conditions for the existence and functioning of entities of different levels. Determining the nature of the threats requires an awareness of their specificity, which is conditioned by both the entity causing the dangerous conditions and the object targeted by those threats. This should take into account the circular cause and effect relationship between the actor and the object, which can change the place in the security structure according to the role function. Thus, the paper tends to focus on the current challenges and new trends in security in the current context in terms of structural and factor tectonics, highlighting their main parameters.

\section{Basic parameters for security threats}

The approach adopted hereby is based on conclusions that specificity of the threat parameters is determined by the nature and place, which the particular threat source or its potential object posses in the security system. Thus, by acting as a security threat, a person can become an actor in terrorist 
activity, including becoming a member of international terrorism as a threat to both national and international security. This requires significant restrictions and increased accountability at the legislative, managerial and social levels with respect to a person in order to prevent him or her from participating in such acts or to stop unlawful criminal activity that is threatening to the safety of other entities. And when a person is the target of threats, the other person's target is another: to have a system of protective and stimulating measures for guarantees of human rights and freedoms and their realization.

The subjective role of society as a carrier of threats is related to the spread of aggressive moods, impatience and intolerance in relations with other actors. Hence the need for information and psychological influence on society, education and upbringing for the sake of correlation or change of mass consciousness, reduction of aggressive intentions and introduction of a tolerant model of social behavior. For society as an object of threats, it is about solving a complex of problems of improving the quality of material and spiritual development, preventing decline in quality and standard of living, preventing stagnation or degradation.

The state as a subject of threats is a source of violent, repressive actions in domestic and foreign policy, which are the bearer of genocide, war, mass terror and so on. In this case, there is an urgent need for severe restrictive measures by the international community in the form of various sanctions, coercion to peace, peacekeeping operations and other forms of cessation of aggression by individual states. The problem is also the loss of the monopoly on the use of force by the state, which significantly expands the range of use of violent methods both in the domestic and in the foreign state. The objective role of the state requires evaluation of the effectiveness of the mechanism for ensuring its sovereignty and integrity.

In the context of threats to the world community, the pace of progressive civilization progress, the elimination of inequalities in geopolitical processes, the prospects of inter-civilizational dialogue, and the introduction of a consensus model of international relations to preserve civilization and further improve it, should be analyzed.

However, the nature of contemporary civilizational, political, and economic clashes causes a wide range of potential threats. And it is precisely this multidimensional and ambiguous nature of the contradictions that arise within the various global and national processes of social development that is the object of scientific analysis in the works of many leading theorists, such as: J. Attali, R. Aron, P. Gauder, S. Huntington, O. Spengler, F. Fukuyama and other authors, who analyzed, simulated and predicted the development of modern world processes that are important for understanding the complex of security problems 
of existence and the functioning of their subjects in different aspects - political, economic, legal, etc. ${ }^{1}$.

For a considerable time, the focus of security researchers was on issues of military and political nature: war, arms race, nuclear weapons and other weapons of mass destruction, terrorism. Today, however, convincingly proves the need, and often the priority, of solving a complex of other important issues of social life. This applies to various areas: law, economics and finance, energy and information, health or the environment, criminal business (drug trafficking, human trafficking), national and religious relations, and so on. These issues, both important and costly, require considerable concerted effort. Therefore, public opinion is forming an understanding of the growing importance of non-military threats and the need to address them in the security plane. It is this wide range of threats that characterizes the multidimensionality of the security category, determines its components and, accordingly, the factors influencing them. The globalization of threats also requires the globalization of their prevention. This is addressed by a set of diplomatic efforts, institutional restructuring of the system of international relations, improvement of legal regulation in various spheres of activity.

An important place in today's world is environmental safety. Environmental pollution, lack of natural resources, drinking water; Earth erosion, «ozone holes», «greenhouse effects», environmental disasters as a result of large-scale natural disasters or technological failures, or the deliberate destruction of environmentally hazardous objects are often regarded as threats, levels, and sometimes more powerful in their adverse effects than the military. Preventing and addressing environmental threats is extremely costly and, according to various estimates, totals up to $\$ 425$ billion, while the global community spends three times less on these needs, which is not enough to overcome such threats.

Epidemiological safety is close to this aspect - the spread of AIDS, «bird flu», Ebola, other dangerous and practically incurable diseases for the given period. Annual challenges to these complex tasks are up to $\$ 15$ billion,

\footnotetext{
${ }^{1}$ Attali J. Millennium; Winners and Losers in the Coming Order. New York. Three Rivers Press. 1992. 135 p.; Aron R. Paix et guerre entre les nations, 8e éd. Paris. Calmann-Lévy, Pérennes, 2004. 749 p.; Fukuyama F. State Building: Governance and World Order in the Twenty-First Century. London: Profile Books Ltd, 2004. 256 p.; Fukuyama F. The End of History and the Last Man. New York: Simon and Schuster, 2006. 432 p.; Gowder P. The Rule of Law in the Real World. New York: Cambridge University Press, 2016. 288 p.; Huntington S. P. The Clash of Civilizations and the Remaking of World Order. New York: Simon \& Schuster, 2011. 368 p.; Spengler O. The Decline of the West. Ed. A. Helps, and H. Werner. Trans. Ch. Atkinson. New York: Oxford University Press, 1991. 480 p.
} 
while real costs do not exceed $\$ 2$ billion ${ }^{2}$. The vast majority of countries affected by these diseases have absolutely no ability to address these issues on their own without international assistance, because, for example, the health budget of a country like Ethiopia, with a population of 105 million, is only $1 \%$ of the richest man of the world - the owner of the Amazon company Jeff Bezos with a fortune of 112 billion dollars, according to the international organization Oxfam, prepared for the forum in Davos, held in January $2019^{3}$.

The development of technology and industry is accompanied by the likelihood of large-scale man-made disasters of chemical, radiological, bacteriological nature, which negatively affects both nature and man.

The depletion of the Earth's natural resources causes a shortage of fuel, energy, and food, posing a threat to human existence itself.

All this stimulates the search for alternative sources of the resource base and optimization of its use, requires the identification of ways to solve a complex set of problems that are vital for humanity in general and specific countries, in particular.

The central actors in the process of ensuring non-military security are states, their governments, intergovernmental organizations. But in this area, the «private sector» of the world community also plays a significant role: national and transnational businesses, national and international public organizations, which put pressure on governments and help them solve pressing problems.

Security threats are also posed by transnational criminal processes (nonpolitical violence) - illegal migration, drug trafficking, human trafficking, hacking, corruption, money laundering. Today it is the uncontrolled illegal mass migration and cybercrime that are becoming especially widespread as security threats, requiring new ways of preventing and overcoming them. Primitive bans and restrictions in these areas are ineffective and can themselves threaten the implementation of human rights legislation or the advancement of new technologies. And a certain balance of permits and prohibitions is important, which stimulates the development of positive trends.

There are problems related to the threat of overpopulation and uneven settlement, which in turn causes problems with the provision of food, water and energy resources. During the second half of the twentieth century, the

\footnotetext{
${ }^{2}$ World health statistics 2016: monitoring health for the SDGs, sustainable development goals. World Health Organization, 2016. 136 p.

3 Public Good or Private Wealth? Oxfam Briefing Paper - January 2019. Oxfamilibrary.openrepository.com: website. URL: https://oxfamilibrary.openrepository.com/ bitstream/handle/10546/620599/bp-public-good-or-private-wealth-210119-en.pdf.
} 
Earth's population doubled, reaching over 7.3 billion. At the same time, in Europe it increased by 1.5 times, and in Africa by 3.3. For example, a population estimate of a country such as Nigeria is estimated at 750 million as of 2100. For comparison, the total population of countries much larger than the European Union is now just 500 million. ${ }^{4}$. Thus, according to the Chinese National Bureau of Statistics, its population grew by 6.6 million in 2018, amounting to 1,427 billion. ${ }^{5}$ Whereas in Ukraine according to the state statistics the population in 2018 decreased by almost 200 thousand people ${ }^{6}$. Such uneven population growth calls for new approaches to the pace and direction of economic development and to the distribution of vital values. Only overcoming hunger alone, food security needs up to $\$ 260$ billion, affecting over 821 million people, or every ninth inhabitant of the planet ${ }^{7}$. This is due to the enormous inequality of wealth when, according to Oxfam, prepared for the World Economic Forum in Davos in 2018, the wealth of just 26 of the world's richest people equals the wealth of 3.8 billion of the world's poorest ${ }^{8}$.

Therefore, any non-military sphere is important and costly and requires a concerted effort to create the safe conditions for the existence of a variety of subjects, from the individual and to humanity as a whole.

Although most theoretical justifications for security are threats to the state, they are expanding the subject field of security of the concept of «human security». After all, security measures are designed to protect both states and citizens from external and internal threats, both military and nonmilitary. Over the past 100 years, a far greater number of people in the world have died, not from the fighting of foreign armies, but from the consequences of the erroneous or ineffective policies of their own governments. The list of major threats to human security should include famine, epidemics and natural disasters that take far more lives than wars and terrorism together.

42016 World Population Data Sheet. Population Reference Bureau: website. URL: http://www.prb.org/Publications/Datasheets/2016/2016-world-population-data-sheet.aspx.

${ }^{5}$ Population of China 2018. Worldometers - real time world statistics: website. URL: https://www.worldometers.info/world-population/china-population/.

${ }^{6}$ Чисельність населення (за оцінкою) на 1 грудня 2018 року та середня чисельність у січні-листопаді 2018 року. Офіційний сайт Державної служби статистики Украӥни. URL: http://www.ukrstat.gov.ua/operativ/operativ2018/ds/kn/xls/kn1118_u.xls.

${ }^{7}$ The State of Food Security and Nutrition in the World 2018. Building climate resilience for food security and nutrition. Rome, 2018. 202 p. The Food and Agriculture Organization of the United Nations: website. URL: http://www.fao.org/3/I9553EN/i9553en.pdf.

8 Public Good or Private Wealth? Oxfam Briefing Paper - January 2019. Oxfamilibrary.openrepository.com: website. URL: https://oxfamilibrary.openrepository.com/ bitstream/handle/10546/620599/bp-public-good-or-private-wealth-210119-en.pdf. 
In many cases, it is the realization of non-military threats that creates the conditions for the emergence and materialization of threats of a military nature and without neutralizing the former it is impossible to combat successfully the latter. Therefore, the UN peacekeeping concept offers a comprehensive approach to addressing both military and non-military threats.

There is an alignment of the priorities of the various spheres of «broad security». Military security somewhat loses its former almost monopoly position of «high politics». At the top of the world engagement agenda, it is cramped by those non-military problems that were previously unconditionally attributed to the category of «low politics».

This transformation is due to a number of objective processes: the growth of the well-being of mankind, the possibility of new technologies to combat non-military threats, the collapse of illusions to «shield» from the negative effects of the disadvantaged part of the world, the expansion of the collective efforts to counter transnational threats, which are globally related; improving security in the military sphere.

In spite of all the problems of confrontation in modern conditions, there was a change in the algorithm of «balancing on the brink of war» and «mutually assured destruction». The likelihood of a nuclear missile strike has declined dramatically, even with the demonstration of nuclear efforts by Iran or North Korea and uncertainty about the real results of reaching a nuclear threat reduction agreement, for example, in the 2018 negotiations between the US, South Korea and North Korea; or despite statements by some Russian officials about the possibility of being transformed into US ash. The end of bipolar confrontation has helped to reduce military spending. In its midst, humanity spent $8.2 \%$ of the world's gross product on military needs, and today it accounts for about $3 \%$. Although this trend has certainly not become entrenched in world politics and, in particular, Russia's aggression against Ukraine has forced European countries to address the issue of increasing military budgets, and some positive developments have already taken place.

For example, the arsenals of weapons of mass destruction, heavy conventional weapons, the number of armed forces, and the volume of arms trade have declined significantly. Full-scale wars between the states have gone. However, forms of political crisis such as local wars, frozen conflicts, and the modern kind of hybrid wars require raising the issue of increased military spending and strengthening military capabilities, including the growing number of armies and expanding military presence. The outbreak of armed conflict occurred in the early 1990s and into the first decades of the 21 st century, caused by the destruction of the bipolar world and geopolitical 
change. And even though wars become less bloody for a certain period, they remain a real threat to human life as the highest value. Thus, according to the 2005 Human Security Report, there was a significant decrease in the intensity of armed conflict, such as the number of combat casualties per year. In 1950, the figure was 38,000 deaths a year in one military conflict, and in 2002, 600 people. ${ }^{9}$. But, as the authors of this research point out, combat casualties give a comprehensive idea of the lethality of combat alone. At the same time, war kills people in less direct but predictable ways, especially when it destroys the economy of society, the infrastructure of medical or social services, public security systems, etc.

In addition, there is now a tendency to increase the mortality rate of armed conflicts. For example, the number of casualties of the unleashed Russian Federation in the East of Ukraine in the conflict from March 2014 to March 2017 alone among the servicemen of the Armed Forces of Ukraine and other security agencies amounted to 2629 dead and 9453 wounded $^{10}$. And these numbers are constantly increasing, because the fighting does not stop. The Fifth President of Ukraine P. Poroshenko, speaking on February 19, 2019 in the Verkhovna Rada of Ukraine, named 2949 dead during the armed aggression of the Russian Federation by Ukrainian servicemen ${ }^{11}$. Human casualties are compounded by the deaths of missing persons, as well as casualties among civilians adjacent to the line of contact. According to the statement of the Ministry of Foreign Affairs of Ukraine on February 20, 2019, the number of victims of the armed confrontation of the Russian Federation during the 5 years is about 13,000 dead and more than 30,000 wounded, nearly 1.5 million people have been displaced ${ }^{12}$. As a result, Ukraine's military expenditures have almost doubled and the number of our country's armed forces has increased. Today, Ukraine is forced to anticipate defense spending at 5\% of GDP. Similar was the reaction of European countries to the growing threat of military conflict. Governments of European countries, USA resolve issues of increase of financing of

\footnotetext{
${ }^{9}$ Human Security Report 2005: War and Peace in the 21st Century / ed. A. Mack. Oxford: Oxford University Press, 2005. P. 31.

10 Лысенко: С начала АТО погибли 2 тыс. 629 украинских военных. 112 Украина: веб-сайт. URL: http://112.ua/ato/lysenko-s-nachala-ato-pogibli-2-tys-629-ukrainskih-voennyh378916.html.

11 Виступ Президента під час спеціального засідання Верховної Ради у зв'язку 3 5-ю річницею з початку збройної агресії Росії проти України. 19 лютого 2019 р. Офіuійне інтернет-представництво Президента України: веб-сайт. URL: https://www.president.gov.ua/ news/vistup-prezidenta-pid-chas-specialnogo-zasidannya-verhovnoyi-53254.

12 Заява МЗС України 3 приводу 5-х роковин початку збройної агресії Росії проти України. 20 лютого 2019 р. Офіційний сайт Міністерства закордонних справ Украӥни. URL: $\quad$ https://mfa.gov.ua/ua/press-center/news/70583-zajava-mzs-ukrajini-z-privodu-5-khrokovin-pochatku-zbrojnoji-agresiji-rosiji-proti-ukrajini.
} 
military-defense complex, number of military presence of NATO, etc. At the NATO Summit in July 2018, there was a commitment to finance at least $2 \%$ of GDP from each Alliance member. In other words, as a result of the spread of armed conflict, economic losses of states increase, supplementing human losses and adversely affecting all processes of democratic development.

Undoubtedly, in the beginning of the 21 st century the total number of victims of all kinds of mass violations of human rights in general decreased.

The only exception is terrorism. The number of large-scale terrorist acts is increasing, there is an increase in the psychological and economic damage caused by them, the cost of combating terrorism is increasing. Although it can be noted that the number of victims of terrorism is less than one percent of the total world casualties from political violence, this trend in military security is unstable. The results achieved do not give rise to euphoria, as every terrorist act robs dozens and hundreds of lives at the same time. And such events take place in the most different countries of the world, on all continents. In 2017-2018 alone, terrorist acts were committed by radical extremist groups of different directions in the United Kingdom, France, Turkey, Sweden, Norway, Pakistan, Afghanistan and several other countries in different parts of the world, taking in each case tens and hundreds of human lives. Therefore, the results of public opinion polls indicate a concern for the state of the world military security itself as a way to protect against terrorist threats.

Partially similar sentiments can be explained by purely subjective reasons. For example, the media focuses on the threats that remain, ignoring the positive developments that have taken place. Attention is drawn to conflicts that start tragically, not those that are peacefully settled, as the threat picture has a greater impact on readers and viewers, widens the reach of potential users and consumers of information, promotes media promotion. It does not bring dividends with a balanced comparative analysis of the past and present security situation and politicians who are afraid to look in the eyes of voters are not sensitive enough to today's threats. Sometimes, security threats are artificially inflated to achieve other goals. But the main reason is the growing demand on the part of the world community for security, both military and non-military, and the lowering of the threshold of tolerance for violations. This raises particular interest in security issues from various political actors.

However, as non-interconnected security areas, they remain specific in nature of threats and means of counteraction to them. And such specifics should not simply be taken into account, but the particularities should be the focus of research in order to find effective ways to solve complex problems. For example, ensuring environmental security requires means, tools and 
political and legal mechanisms other than those needed to resolve inter-state armed conflicts or to combat terrorism. The algorithms for the operation of different security areas are unique. They are combined by a common negative impact, and often a deadly effect on the combined security of the individual, country, region and the entire global community. But a comprehensive approach to security should not negate the features of each of its components. It is the specificity of individual subsystems that creates a multidimensional, non-linear vision of the current state of security. This takes into account the various features of the security process with all its components and in different dimensions and aspects. All this allows predicting the behavior of the entire security system and setting up basic criteria for evaluation its status.

\section{Criteria for assessing the state of the security system and its components}

The main criterion for assessing the security situation is the stability indicator, both internal and external. After all, stability is the meaning of the functioning of security mechanisms, without excluding the dynamics of processes and change of forms.

Stability studies cover a wide range of problems, from the absence of war to the evaluation of integrative interaction, from the invariance of structures to the analysis of their dynamic models. They can be divided into two groups. For the first group, the initial postulate is the strong link between the stability of international systems and the configuration of their structures. And within the second, stability is characterized in the abstract, defining the conditions for maintaining stability in any structured system. The first group includes the works of L. Geddis L. Miller, K. Waltz, and others ${ }^{13}$; to the second one - K. Boulding, T. Schelling, O. Bogaturov and others ${ }^{14}$. All of these studies have broadened the theoretical understanding of stability by analyzing it as a systemic parameter of security and finding the difference between static and dynamic measurements of stability.

Stability and development mechanisms have been identified as autonomous, linked to different components of the system that require

\footnotetext{
${ }^{13}$ Miller L. Global Order. Values and Power in International Politics. Boulder: Westview Press, 1994. 269 p.; Waltz N. K. Theory of International Politics. Reading: Addison-Wesle, 1979. 251 p.; Gaddis J. L., The Cold War: A New History. New York: Penguin Press, 2005. 334 p.

${ }^{14}$ Boulding K. E. Conflict and defense: a general theory. New York: Harper \& Brothers, 1962. 349 p.; Schelling T. C. The Strategy of Conflict. Reprint, illustrated and revised. ed. Cambridge, MA: Harvard University Press, 1980. 309 р.; Современная мировая политика: прикладной анализ / Ред. А. Д. Богатуров. М.: Аспект Пресс, 2010. 592 с.
} 
different approaches to their study. The variability of such a study is due to the structural-genetic analysis of the object, which as a result constructs a number of theoretical models that describe the states of stability, or statistical parameters that characterize the interaction of structural elements of complex systems. It is particularly important to analyze the behavior of such systems in motion, that is, dynamic stability as a system parameter inherent in the modern multipolar world, which contributes to the restoration of the stability of the relations system between states and thus stimulates their internal stability. But this principle cannot be equated with the risk of achieving stability at any cost, sacrificing the stability of interests of particular states, concessions to power, etc. There are certain taboos fixed by the international legal norms and rules of civil interaction.

But interaction is most clearly manifested in conflict, so defining the notion of stability for international relations in one way or another included the problems of war and peace. They have completed the form in the works of American scientists K. Deutsch and D. Singer. By definition, stability is the likelihood that the system retains its basic characteristics and there is no large-scale war $^{15}$. Thus the absence of war was not an attribute, but one of the signs of systemic stability, its consequence. Understanding stability as a factor inherent in the international structure from the beginning is characteristic of neorealism. The configuration of the structure in the interpretation of the representatives of this current contains a factor that prevents states from taking action that threatens the very existence of the system and continuing to exist means stability. However, such an interpretation gives to the integral structure an overriding role in shaping the behavior of its elements, eliminating the possibility of influence of individual states on the configuration of the international structure. In this embodiment, stability acts as an attribute of the «general» and is independent of the action and interaction of the «special». Such logic narrows the notion of stability, introduces it into the framework of structural parameters of a holistic system only, and does not take into account the role of specific states in creating and maintaining the stability of the international system. This, in turn, underestimates the dynamics of change throughout the system as an adequate response to the positions of its individual elements. But the analysis of the current state of the system of international relations

15 Deutsch K., Singer D. Multipolar Power Systems and International Stability. In Analyzing International Relations: a Multimethod Introduction. Colpin W. (eds.). New York: Praeger, 1975. $321 \mathrm{p}$. 
convincingly proves that the mechanisms of maintaining stability lie in the plane of behavior of its individual elements. This tendency is confirmed by the criticism of current politicians and scholars of the place and role in the security of an institution such as the UN as a whole, or of the UN Security Council in particular, and the justification of the urgent need to reform them.

A definite solution to the contradiction in understanding the concept of stability is the definition proposed by O. Bogaturov. In his view, stability should be considered as a certain type of movement of the system of interstate relations, a movement relatively smooth, uniform and predictable, under which the system is able to exist, reproduce and change without losing its basic characteristics. Stability characterizes the ability of a system to provide the changes necessary for its self-preservation, compensating for them so that the loss of individual elements and characteristics does not pose a threat to the survival of the system as a whole ${ }^{16}$. Such a definition is based on the recognition of the dynamic nature of the system of interaction of states, on the understanding of the need to create safe conditions for their coexistence, which ultimately aims to stimulate the development of each individual state and provides for strengthening its own security as a guarantee of security of other subjects of international relations.

Therefore, the attention of theorists in the second half of the twentieth century, the comparison of stability mechanisms under conditions of transition from bipolar to multipolar world order was given. The works of D. Baldwin, K. Booth, B. Schmidt, L. Miller, L. Geddis and other authors were devoted to the problems of connection between the structure of the international system and its stability. They outline the main approaches to creating safe conditions for development. The first approach emphasized states' capacity for self-restraint to maintain stability and prevent destruction. However, the «collective goods» theory underlying this approach has drawbacks either due to the neglect of opportunities or the desire to reduce one's own losses. A clear confirmation of such contradictions is the current migration policy of European states, its ambiguous assessment and perception by governments and the societies of individual states. This is evidenced by the difficult talks between EU leaders at the Brussels summit on June 28, 2018, covering issues such as migration, security and protection, jobs, growth and competitiveness, innovation and C. 34 .

${ }^{16}$ Богатуров А. Великие державы на Тихом океане. М.: Конверт - МОНФ, 1997. 
digital technologies, etc. ${ }^{17}$ In such situations, the collective security system in many cases becomes ineffective, as demonstrated today by the UN Security Council, requiring changes that will stimulate the coherence of individual states' actions in order to overcome existing security contradictions and not to be held hostage by individual members overburdened.

The second approach pays more attention to national security features that must be taken into account at both interstate and supranational levels, influencing structural changes in the security system as a whole. After all, national security is a subsystem, a structural element of collective security in today's globalized environment.

National security is characterized by all the features of systematicity: integrity, interconnection, interaction of structural components, their coordination, subordination and so on. The concept of entirety expresses the integrity, self-sufficiency, autonomy and activity of objects. It characterizes their qualitative originality due to specific patterns of functioning and development.

Depending on the location of the source of the danger, national security is divided into two types - internal and external. Each type of security, each such subsystem, in turn, also acts as a system in relation to its components. That is, a certain structural hierarchy is built up.

The structure of a security system is a set of strong relationships and links between the elements that ensure its integrity. And the quality of the security system is determined by the elements themselves (subsystems) and their interaction. All components must be organically interconnected. Interaction is a category that reflects the processes of action of different components on each other, their mutual conditionality, change of state, interaction and creation of others.

The interconnections between elements, system levels, between subsystems can be different: constant and variable, necessary and random, stable and unstable, mutually stimulating, interacting and mutually exclusive.

Interaction is not only a joint and concerted action, but a kind of relationships and links between objects. Any interaction consists of two components: unity and the struggle of the parties involved, or their

7 European Council conclusions. 28 June 2018. Consilium: website. URL: https://www.consilium.europa.eu/en/press/press-releases/2018/06/29/20180628-eucoconclusions-final/. 
promotion, which is a form of unity but does not come down to it completely. The unity of the security system is manifested in the dynamic connection, the interdependence of its structural elements, the continuity of the components of the common security, the inability to achieve it through efforts in one area alone, notwithstanding the other components.

This dynamic link exists between all elements of the security system. At the same time, these elements are not equal in the general system. Their place and role are determined by the extent of external and internal threats.

The structural components of the security system include: actors and objects of the security system; views, goals, principles, concepts, security doctrines of various fields; legal rules governing relations in the field of ensuring each type of security; resources for providing specific types of security; the vital interests of society, the state and the individual as a reflection of their objective needs; information on the dangers and threats to the vital needs of the individual, society and the state; methods and ways of security activities and their results.

Functional components of the security system demonstrate the basic connections of structural components that arise in the process of its functioning. Among them are: organizational - implementation of a certain administrative action on the elements of the system with the aim of consistency of actions; communicative - establishing appropriate interaction between the structural components of the system in the course of its functioning through the transmission of information; constructive - the selection and modeling of action on the system at each stage of achievement of goals, as well as determining the features of activities to ensure a specific type of security in specific historical conditions; design, which includes programming and forecasting activities to achieve the goals of the system; epistemological - the accumulation and analysis of new knowledge about the security system and ensuring its functioning.

Thus, the system of security means a specially created in the country a set of interacting entities, their official views, concepts and doctrines, enshrined in the relevant legal norms, as well as the forces, means, methods and directions that guarantee the quality of the society, its structures and institutions in the parameters of the guarantee of existence and sustainability of development, by eliminating the dangers and threats, their prevention, warning and elimination.

Within the system of a particular type of security several large subsystems interact: institutional, regulatory, functional, information and 
communication, cultural and ideological, each of which has its own characteristics.

The institutional subsystem is the basis of the security system. This subsystem plays a key role in the security system; conditions are ensured to ensure the effectiveness of the security mechanism, forms of interaction with other national security subsystems, as well as international security systems. It is here that the purpose and directions of the functioning of this system are essentially determined through the outlined competencies of the individual elements.

As a security system is a social system, it includes a system of social interactions between individuals, society, the state and the international community and the conditions for preventing or eliminating the dangers and threats posed to the organization. The main elements of this social interaction are actors - carriers of activity, which are inherent in the ability to be an independent source of activity, to realistically and directly influence the course of events, to change reality, thereby to promote the security of man, society and the state and to guarantee their own security, respectively.

The part of the political organization of the society that is directly concerned with security in each of the spheres of life is the institutional actor: it defines the goals of security necessary for its attainment of ways, forces, means, forms and methods of activity; organizes their interaction, manages the security mechanism related to the creation and use of special means. It is, first of all, the state - the system-forming subject of security, in particular its bodies of legislative, executive and judicial power, as well as their specialized institutes, which ensure the security of a specific sphere of life activity.

Institutional actors are also non-state institutions - political parties, public organizations and socio-political movements.

The actors of the social spectrum are social groups, communities (ethnic groups, executions, society as a whole), individual citizens, etc. Social interaction of these entities takes place in all spheres of society.

It is these different actors who make decisions aimed at affirming the safe conditions of their existence and functioning. The implementation of such solutions creates a field of interaction between these actors. The subject of this interaction is the needs and interests of individuals, social groups, social communities and communities.

In today's context, it is necessary to take a comprehensive account of the possible consequences of decisions that are made in certain areas of life and 
affect security. Therefore, the effectiveness of the security system depends on the availability of communicative-managerial capability (or intelligence) of the system, its awareness, as well as the coherence of actions to prevent and counteract hazards and threats. It is in this complex that a modern system of systems is formed.

Intelligence of a security system means its ability to make and timely implement the most effective solutions to prevent, neutralize or eliminate appropriate means of emerging hazards and threats; for the development and implementation of sound policies designed both for the long-term perspective of supporting sustainable development and for operational intervention in situations capable of generating tension or instability in society.

Security awareness is the ability to receive, store and process information in a timely manner to detect and respond adequately to hazards and threats using the available means and capabilities.

An important subsystem of the security system is the cultural and ideological subsystem. Security ideology is a systematic set of ideas and views on the security of states and citizens. It contains the ideological basis of the content of the existence of the state and is based on the synthesis of the accumulated knowledge to ensure a decent life of people both in terms of national and international experience.

The objects of safety are the various spheres of life activity, in which both the people themselves and their technology and the social structures of society, the state are involved; and finally the environment. In other words, there are different components to a security system when viewed vertically or horizontally. These are interrelated and interdependent components, but their place, hierarchy, role are determined by a number of circumstances, among which priority is the nature of public relations, political structure, the volume of external and internal dangers.

In the current model of relations «person - civil society - state» the relations between the elements must be built according to a concrete scheme. In the first place should be the person as the main object and at the same time the main actor of security, which through mechanisms of democracy and institutions of civil society delegates the most important powers to the state, exercising public control over it, but without encroaching on the inalienable, recognized by all right. Such cooperation is carried out within the framework of the social partnership model, where everyone's capabilities work for a common purpose - security. 
For the state, in this context, the purpose of existence and development, the criterion of effectiveness is the real guaranteed rights and freedoms, quality and standard of living. Only in this sense the person is the highest value, the criterion for the welfare of society.

The state and civil society in such a system of interconnections act as a means of preserving this value and achieving the goal of development, but man is the main resource of the state for the protection of his own interests in form, but public in essence.

Thus, the main interest of the state is the comprehensive (physical, spiritual and intellectual) development of the individual. Protection of the constitutional order, sovereignty and territorial integrity of the state; establishment of political, economic and social stability; unconditional implementation of laws and support of law and order, development of international cooperation - effective ways of ensuring the main interest of the state - comprehensive development of personality.

Hence the ideal security model: as the highest value for the functioning of the national and international security system, a person delegates some of the authority to ensure his or her own security to civil society, society, in turn, the state; and the state, to some extent, to the international community. The interconnection of national, international and global security and their interdependence is built on this approach. But nevertheless, the state remains the center of the security mechanism at national, interstate and even suprastate levels.

Recognizing the state as the center of the political system, an instrument of power, we emphasize its ability to prevent, neutralize, localize, weaken, eliminate the dangers and threats to the political system, the territorial integrity of the country, and the life of its population.

In this sense, the security of the state acts as the basis for maintaining the life of the system, which characterizes the qualitative certainty in the parameters of the reliability of existence and sustainability of the state as a whole, and society as a whole and its individual citizens. The security of the state can be ensured by the existence of an effective mechanism for managing and coordinating all social forces of society, as well as effective institutions for their protection.

A sovereign phenomenon is also the safety of society, characterized by a number of features: opportunities for the free development of public life, the sphere of mass movements, parties, unions by conviction and any other attribute; the development of the collective function; implementation of 
compromise interaction between majority and minority; the ability to limit and overcome political alienation within a tolerant model of interaction; sustainable development and preservation of material and cultural values, progressive traditions; non-interference with the sphere of a person's personal life.

The safety of society is guaranteed by the presence of public institutions, norms, developed forms of social consciousness and culture, which allow to exercise the rights and freedoms of all population groups and to resist the actions leading to the split of society. Thus, the security of society is a quality state of social relations that ensures the progressive development of man and society in specific historical and natural conditions, guaranteeing the protection and extension of rights and freedoms, the realization of needs and interests.

When addressing the issues of security in the area of state security and public safety, we constantly cross the area of personal security of citizens, face human security, its position in society, the opportunity to live and work in proper conditions, to realize our material and spiritual needs. In this perspective, human security is a priority in the whole security scheme, characterized by a real guarantee of constitutional rights and freedoms, its access to health, education, and culture systems; opportunity to choose activities by vocation, social guarantees for compensation of labor costs, absence of violent forms of coercion, etc. The personal security is granted by public institutions and organizations, the state, a set of moral and national and international legal norms that allow it to develop and realize socially significant needs and interests without confronting the opposition of the state and society.

All this indicates that the criteria for assessing the security situation is to be different and directly related to the specific subject and security object involved in the process of democratic transit.

\section{CONCLUSIONS}

Thus, it can be concluded that since security is a systemic phenomenon, it has a number of constituent elements that reproduce the diversity of internal and external, essential and irrelevant, necessary and accidental connections and communications, stimulating modern forms of interaction that cover institutional, regulatory and procedural spheres. Such a holistic system vision provides for the possibility of a comprehensive analysis of national and international security systems and mechanisms for their 
provision in the aspect of the general characteristics of the basic parameters of the modern security structure and algorithms of functioning of different security areas, emphasizing on the basic criteria for the assessment of safety states. At the same time, the dynamics of forms are accompanied by qualitative changes in their substantive content, in accordance with changes in the conditions of existence and functioning and the emergence of new challenges and threats to the system as a whole or its individual elements. In this case, tectonics occurs both vertically and horizontally and requires the creation of new security models and the improvement of methods of providing it. Meeting these requirements becomes essential, because a sufficient security status appears the basic guarantee of a progressive democratic development in the modern world. This is especially important for countries in democratic transit whose democratic transformations have not been completed in order to prevent the threat of restoration of the undemocratic format of the state's existence and functioning. Ukraine belongs to this category, following the path of deepening democratic reforms that meets the public needs and demands. Therefore, security problems, especially in the face of aggression of the Russian Federation, are vital. Only safe living conditions may grant Ukraine's democratic progress. Meeting such conditions have a capacity to ensure the attractiveness of democratic transformations both for national society itself and for the external democratic environment.

\section{SUMMARY}

Security as a systemic phenomenon is a guarantee of successful democratic transformations, which determines the special role of this category in the analysis of the process of democratic transit. The security states of different actors: human beings, societies, states have a specific nature and characteristics whose understanding opens up opportunities for refining political strategies. The current era creates new security challenges and trends, requiring the creation of appropriate security models and mechanisms. The basic parameters of threats are caused by circular cause and effect interdependence between elements of the security system. The main criteria for assessing the security situation as determinants of the democratic transit process are due to the parameters of dynamic stability. Creating a safe environment ensures successful democratic progress in all spheres of life, both nationally and internationally. 


\section{REFERENCES}

1. Aron R. Paix et guerre entre les nations, 8e éd. Paris. Calmann-Lévy, Pérennes, 2004. 749 p.

2. Attali J. Millennium; Winners and Losers in the Coming Order. New York. Three Rivers Press. 1992. 135 p.

3. Boulding K. E. Conflict and defense: a general theory. New York: Harper \& Brothers, 1962. 349 p.

4. Deutsch K., Singer D. Multipolar Power Systems and International Stability. In Analyzing International Relations: a Multimethod Introduction. Colpin W. (eds.). New York: Praeger, 1975. 321 p.

5. European Council conclusions. 28 June 2018. Consilium: website. URL: $\quad$ https://www.consilium.europa.eu/en/press/press-releases/2018/ 06/29/20180628-euco-conclusions-final/.

6. Fukuyama F. State Building: Governance and World Order in the Twenty-First Century. London: Profile Books Ltd, 2004. 256 p.

7. Fukuyama F. The End of History and the Last Man. New York: Simon and Schuster, 2006. 432 p.

8. Gaddis J. L.,The Cold War: A New History. New York: Penguin Press, 2005. 334 p.

9. Gowder P. The Rule of Law in the Real World. New York: Cambridge University Press, 2016. 288 p.

10. Huntington S. P. The Clash of Civilizations and the Remaking of World Order. New York: Simon \& Schuster, 2011. 368 p.

11. Human Security Report 2005: War and Peace in the 21st Century / ed. A. Mack. Oxford: Oxford University Press, 2005. 170 p.

12. Miller L. Global Order. Values and Power in International Politics. Boulder: Westview Press, 1994. 269 p.

13. Population of China 2018. Worldometers - real time world statistics: website. URL: https://www.worldometers.info/world-population/chinapopulation/.

14. Public Good or Private Wealth? Oxfam Briefing Paper - January 2019. Oxfamilibrary.openrepository.com: website. URL: https://oxfamilibrary.openrepository.com/bitstream/handle/10546/620599/bp -public-good-or-private-wealth-210119-en.pdf.

15. Schelling T. C. The Strategy of Conflict. Reprint, illustrated and revised. ed. Cambridge, MA: Harvard University Press, 1980. 309 p.

16. Spengler O. The Decline of the West. Ed. A. Helps, and H. Werner. Trans. Ch. Atkinson. New York: Oxford University Press, 1991. 480 p.

17. The State of Food Security and Nutrition in the World 2018. Building climate resilience for food security and nutrition. Rome, 2018. 202 p. The 
Food and Agriculture Organization of the United Nations: website. URL: http://www.fao.org/3/19553EN/i9553en.pdf.

18. Waltz N. K. Theory of International Politics. Reading: AddisonWesle, 1979. $251 \mathrm{p}$.

19. World health statistics 2016: monitoring health for the SDGs, sustainable development goals. World Health Organization, 2016. $136 \mathrm{p}$.

20.2016 World Population Data Sheet. Population Reference Bureau: website. URL: http://www.prb.org/Publications/Datasheets/2016/2016world-population-data-sheet.aspx.

21. Богатуров А. Великие державы на Тихом океане. М.: Конверт МОНФ, 1997. $353 \mathrm{c}$.

22. Виступ Президента під час спеціального засідання Верховної Ради у зв'язку з 5-ю річницею з початку збройної агресії Росії проти України. 19 лютого 2019 р. Офіиійне інтернет-представництво Президента Украӥни: веб-сайт. URL: https://www.president.gov.ua/news/ vistup-prezidenta-pid-chas-specialnogo-zasidannya-verhovnoyi-53254.

23.Заява МЗС України з приводу 5-х роковин початку збройної агресії Росії проти України. 20 лютого 2019 р. Офіuійний сайт міністерства закордонних справ Украӥни. URL: https://mfa.gov.ua/ua/press-center/news/70583-zajava-mzs-ukrajini-zprivodu-5-kh-rokovin-pochatku-zbrojnoji-agresiji-rosiji-proti-ukrajini.

24. Лысенко: С начала АТО погибли 2 тыс. 629 украинских военных. 112 Украина: веб-сайт. URL: http://112.ua/ato/lysenko-snachala-ato-pogibli-2-tys-629-ukrainskih-voennyh-378916.html.

25. Современная мировая политика: прикладной анализ / Ред. А. Д. Богатуров. М.: Аспект Пресс, 2010. 592 с.

26. Чисельність населення (за оцінкою) на 1 грудня 2018 року та середня чисельність у січні-листопаді 2018 року. Офіщійний сайт Державної служби статистики України. URL: http://www.ukrstat.gov.ua/operativ/operativ2018/ds/kn/xls/kn1118_u.xls.

\section{Information about the author:} Kormych L. I., Doctor of History, Professor, Head of the Department of Political Theories of the National University «Odessa Law Academy» 2, Academichna str., Odesa, 65009, Ukriane 